\title{
AKÉ SÚ MOŽNOSTI VYUŽÍVANIA ODPADOVÉHO TEPLA Z BAZÉNOVEJ VODY?
}

\author{
WHAT ARE THE POSSIBILITIES OF USING SWIMMING POOL \\ WASTEWATER HEAT?
}

\author{
Anna Predajnianska*,1 \\ "predajnianska.anna@gmail.com \\ ${ }^{1}$ Slovenská technická univerzita v Bratislave, Stavebná fakulta, Katedra technických zariadení budov, Radlinského 11, 81005, Bratislava
}

\begin{abstract}
Abstrakt
Termálne kúpaliská na Slovensku sú producentmi odpadových vôd, ktoré v sebe ukrývajú značný energetický potenciál. Odpadová voda často prekračuje maximálnu prípustnú teplotu, ktorá môže byt’ odvádzaná do recipientu bez poškodenia životného prostredia. V mnohých prípadoch je táto teplota prekročená a prevádzkovatelia kúpalísk musia čelit' sankciám za znečist'ovanie životného prostredia. Ciel'om príspevku je predstavit' možnosti, využitia energetického potenciálu odpadovej vody, čím by bolo možné zabezpečit' jej požadovanú teplotu.
\end{abstract}

\section{Klíčová slova}

Odpadová bazénová voda, Energetický potenciál, Spätné získavanie tepla, Termálne kúpaliská, Geotermálna energia

\begin{abstract}
Thermal baths in Slovakia are producers of wastewater, which have considerable enegry potential. Wastewater often exceeds the maximum temperature that can be discharged to the recipient without harming the environment. In many cases, this requirement is not met, and swimming pool operators must face sanctions for environmental pollution. The aim of the paper is to present the possibilities of using the energy potential of wastewater, which would ensure its required temperature.
\end{abstract}

Key words

Waste pool water, Energy potential, Heat recovery, Thermal baths, Geothermal energy

\section{1 ÚVOD}

V súčasnosti máme na Slovensku 35 termálnych kúpalísk a 209 umelých kúpalísk. V rámci areálov týchto kúpalísk hovoríme o nemalom počte bazénov. Na Slovensku máme k dnešnému dňu registrovaných 469 bazénov, plnených netermálnou vodou a 189 bazénov plnených termálnou vodou. Termálne, ale aj netermálne kúpaliská poskytujú obrovský energetický potenciál v podobe odpadovej bazénovej vody, ktorú produkujú. Príspevok je zameraný na termálne kúpaliská, ktoré vo svojich prevádzkach využívajú geotermálnu vodu na plnenie bazénov. Geotermálna energia je považovaná za obnovitel'ný zdroj energie. V súčasnosti máme na Slovensku 32 oblastí s geotermálnym potenciálom. V týchto oblastiach môžeme nájst' až 176 geotermálnych vrtov, ktoré poskytujú vodu s teplotou až do $130{ }^{\circ} \mathrm{C}$ [1], [2]. Geotermálna energia je na Slovensku využívaná rôznymi spôsobmi. Nie vel'mi známy spôsob využitia tejto energie je v rybích farmách, kde sa geotermálna voda využíva na ohrev vody, ktorá je napúšt’aná do jednotlivých nádrží s rybami. Ovel’a známejší spôsob využitia je pre vykurovacie sústavy skleníkov a fóliovníkov. Rozsiahle skleníkové hospodárstva, využívajúce geotermálnu energiu na ohrev, máme na juhu Slovenska, kde sa pestujú predovšetkým paradajky (Horná Potôň), uhorky (Zemné) a gerbery (Vlčany). Geotermálnu energiu je možné využívat' aj v systémoch centralizovaného zásobovania teplom, pričom na Slovensku máme niekol'ko funkčných aplikácií (Galanta, Sered', Šal'a). V najväčšej miere je geotermálna energia využívaná práve na rekreačné účely v termálnych a balneologických zariadeniach.

V rámci príspevku budeme pojednávat' najmä o termálnych kúpaliskách, ktoré vo svojich prevádzkach využívajú geotermálnu vodu. Ako už bolo naznačené, v mnohých prípadoch sa stretávame $\mathrm{s}$ nepriaznivou situáciou, kedy je z prevádzok vypúšt’aná odpadová bazénová voda s príliš vysokou teplotou. Maximálna teplota odpadovej bazénovej vody, ktorá môže byt' vypustená do recipientu bez poškodenia okolitého životného 
prostredia, je stanovená na hodnotu $26^{\circ} \mathrm{C}$ [3], [4]. Toto predpisuje Zákon č. 364/2004 Z. z. o vodách a o zmene zákona Slovenskej národnej rady č. 372/1990 Zb. o priestupkoch v znení neskorších predpisov (známy tiež ako vodný zákon) v súčinnosti s Nariadením vlády Slovenskej republiky č. 239/2010 z 25. mája 2010, ktorým sa ustanovujú požiadavky na dosiahnutie dobrého stavu vôd. Ciel'om príspevku je predstavit' niekol'ko možností užitočného využitia energetického potenciálu, ktorý v sebe nesie odpadová bazénová voda.

\section{SÚČASNÝ STAV SPÄTNÉHO VYUŽÍVANI TEPLA}

Myšlienka spätného získavania tepla všeobecne z odpadovej vody ako zdroj energie nie je v súčasnosti ničím nevšedným. Teplo z odpadovej vody disponuje vel'kým energetickým potenciálom a dá sa využit' jednoducho, s ohl'adom na okolité životné prostredie. Vzhl'adom na aktuálne diskusie o klimatických zmenách, ide o vel'mi zaujímavú technológiu.

Vo Švajčiarskom Muri bol vytvorený projekt, ktorý zabezpečuje vykurovanie 32 rodinných domov osobitným zdrojom energie - odpadovou vodou z tamojšej čistiarne odpadových vôd. Systém funguje na princípe tepelných čerpadiel zapojených do kaskády, ktoré získavajú energiu na vykurovanie z čistiarne odpadovej vody. Doskový výmenník tepla odoberá teplo a vedie ho cez uzavretý okruh do tepelných čerpadiel. V prípade potreby je k dispozícii aj kotol na vykurovací olej, ktorý doposial' nebolo potrebné využívat' [5].

Další zaujímavý spôsob využívania odpadového tepla je z kanalizácie. Toto teplo je možné využit' na ohrev teplej vody v budovách. Systém je založený na odovzdávaní tepla zo splaškovej odpadovej vody cez teplo výmennú plochu výmenníka tepla, ktorý môže byt’ integrovaný priamo v budove, prípadne mimo budovy v prípade jeho väčších rozmerov. Získané teplo je možné využit' na prípravu teplej vody v budove [6].

Zmienky o systéme spätného získavania tepla z odpadovej bazénovej vody doposial' neboli zverejnené odborníkmi v danom odbore na Slovensku, ani vo svete. Preto ciel'om príspevku je predstavit' spôsoby, ako by bolo možné užitočne využívat' odpadové teplo z bazénovej vody. Na Slovensku to predstavuje obrovský energetický potenciál vzhl’adom na počet bazénov v termálnych, ale aj netermálnych kúpalísk.

\section{Možnosti spätného využívania tepla z odpadovej bazénovej vody}

V areáloch rekreačných zariadení môžeme nájst' množstvo rôznych druhov bazénov. Z hl'adiska návštevníka kúpaliska je zaujímavá predovšetkým teplota bazénovej vody, prípadne či má voda liečivé účinky. Z hl’adiska odborníka na návrh energetických systémov sú zaujímavé mnohé d’alšie vlastnosti každého z bazénov. Pri riešení energetickej bilancie celého bazénového hospodárstva, je potrebné oboznámit' sa $\mathrm{s}$ fungovaním a celkovou prevádzkou jednotlivých bazénov. Dôležitými vlastnost’ami sú pôdorysné rozmery, vodná plocha, híbka, objem bazéna, požadovaná teplota vody v bazéne, požadovaná výmena vody v bazéne, spôsob plnenia bazéna, bazénový systém a v neposlednom rade vplyv klimatických podmienok na tepelné straty bazéna. Pri systéme spätného využívania tepla má najväčší potenciál odpadová bazénová voda z rekreačných bazénov, kde je požadovaná teplota vody v bazéne v rozmedzí $35-40{ }^{\circ} \mathrm{C}$. Vd’aka podrobnému oboznámeniu sa s prevádzkou bazéna, je možné vypočítat' energetickú bilanciu. V rámci výpočtov je možné vyčíslit’ nie len energiu, ktorú v sebe nesie odpadová bazénová voda. Túto energiu je možné d'alej využívat' niekol'kými užitočnými spôsobmi:

- $\quad$ predohrev studenej vody využívanej v bazénoch ako vodu miešanú s geotermálnou vodou,

- predohrev pre prípravu teplej vody,

- rozmrazovanie chodníkov,

- aktívna tepelná ochrana budov.

Princíp systému spätného získavania tepla je založený na vložení regeneračného výmenníka tepla do okruhu odpadovej bazénovej vody. Vo všetkých hore uvedených prípadoch, je potrebné využívat' výmenník tepla, ktorým bude prúdit' primárna a sekundárna teplonosná látka. Primárnou teplonosnou látkou bude odpadová bazénová voda s teplotou v rozmedzí $35-40{ }^{\circ} \mathrm{C}$. Sekundárnou látkou bude studená voda.

Odpadové teplo je možné využit' ako predohrev pre systém prípravy teplej vody. Odpadová bazénová voda s teplotou do $40{ }^{\circ} \mathrm{C}$ poskytuje energetický potenciál, vd'aka ktorému by bolo možné čiastočne predhriat' studenú pitnú vodu. Následne by predhriata voda bola privedená do zásobníkového ohrievača teplej vody, kde by sa dohriala na požadovanú teplotu.

Každé bazénové hospodárstvo disponuje aj exteriérovými bazénmi a teda komunikačnými priestormi medzi jednotlivými bazénmi, ktoré je možné využívat’ aj v zimnej prevádzke. Samozrejme sa jedná o rekreačné, alebo oddychové bazény, v ktorých teplota bazénovej vody dosahuje teplotu do $40{ }^{\circ} \mathrm{C}$. V prípade zimnej prevádzky sa prevádzkari stretávajú s problémom odhadzovania snehu, prípadne s námrazou vznikajúcou na chodníkoch. V mnohých prípadoch nastáva problém, že sneh nemajú kde uskladňovat'. Tento problém by bol riešitel'ný taktiež 
pomocou využitia energetického potenciálu z odpadovej bazénovej vody daného bazénového hospodárstva. Je tu možnost' vytvorit' potrubný systém, zabudovaný v chodníku, ktorým bude prúdit' nemrznúca kvapalina ako sekundárna látka. Primárnou látkou bude odpadová geotermálna voda. Vd’aka dostatočnej teplote vody by dochádzalo $\mathrm{k}$ eliminácii námrazy a $\mathrm{k}$ rozpúšt’aniu snehovej pokrývky chodníkov. Tento systém je vo svete využívaný na rozmrazovanie chodníkov, ale aj ciest. Aplikácie môžeme nájst' najmä na Islande, v Číne, ale aj v Kanade.

Systém aktívnej tepelnej ochrane je pomerne známy na Slovensku aj vo svete. Hlavnou funkciou systému je znižovat' tepelné straty netransparentných konštrukcií v zime a súčasne znižovat', alebo eliminovat' tepelné zisky $\mathrm{v}$ lete. Systém aktívnej tepelnej ochrany pozostáva z potrubného systému, zabudovaného do stavebných konštrukcií. Cez potrubný systém cirkuluje pracovná teplonosná látka, ktorá môže byt' ohrievaná rôznymi zdrojmi tepla. Jednou z možností je aj predohrev teplonosnej látky pomocou odpadového tepla z bazénovej vody. Úlohou systému je vytvorit’ aktívnu tepelnú bariéru medzi interiérom a exteriérom [7].

\section{Predohrev studenej vody využívanej na plnenie bazénov}

V bazénových hospodárstvach sú využívané dva základné typy bazénových systémov. Prvým je prietokový systém, pri využití ktorého je bazén napúšt’aný priamo geotermálnou vodou. Toto je možné za predpokladu, že geotermálna voda má vyhovujúce mineralogické zloženie a požadovanú teplotu. V prípade, že je potrebné geotermálnu vodu upravovat' už či z mineralogického hl'adiska, alebo z hl'adiska teploty, je možné využit' taktiež prietokový systém, avšak doplnený o primiešavanie studenej vody. V takomto prípade sa geotermálna voda mieša so studenou tak, aby sme dosiahli požadovanú teplotu bazénovej vody. Zmiešaná bazénová voda je väčšinou pred vypustením do bazéna chemicky upravovaná. Technicky náročnejší, ale viac využívaný je cirkulačný systém. Súčast'ou tohoto systému je vyrovnávacia nádrž, v ktorej sa mieša geotermálna, studená a bazénová voda. Bazénová voda z priepadov a odtokov bazéna je privádzaná opätovne do vyrovnávacej nádrže, pred filtračné zariadenie. Až po preplnení vyrovnávacej nádrže, odteká zo systému odpadová bazénová voda [8]. Násobnost' výmeny bazénovej vody za 24 hodín stanoví orgán Hygienickej služby. Násobnosti výmeny bazénovej vody za 24 hodín sa líšia v závislosti od použitia prietokového a cirkulačného systému. Pri prietokovom systéme sú násobnosti výmeny vody niekol'ko násobne vyššie ako pri cirkulačnom systéme.

Predohrev studenej vody spočíva vo vradení rekuperačného výmenníka tepla do okruhu odpadovej bazénovej vody. Cez výmenník tepla bude prúdit’ odpadová bazénová voda, ktorá odovzdá svoje teplo studenej vode, ktorá sa mieša s geotermálnou vodou na dosiahnutie parametrov bazénovej vody. Vzhl'adom na to, že do zmiešavacieho uzla bude privedená predhriata studená voda, bude potrebný menší objem geotermálnej vody. Dôsledkom toho dôjde $\mathrm{k}$ predíženiu životnosti geotermálneho energetického systému a zároveň $\mathrm{k}$ zníženiu teploty odpadovej bazénovej vody. Systém spätného získavania tepla z odpadovej bazénovej vody s využitím na predohrev studenej vody v bazénovom hospodárstve je uvedený na Obrázku 1.
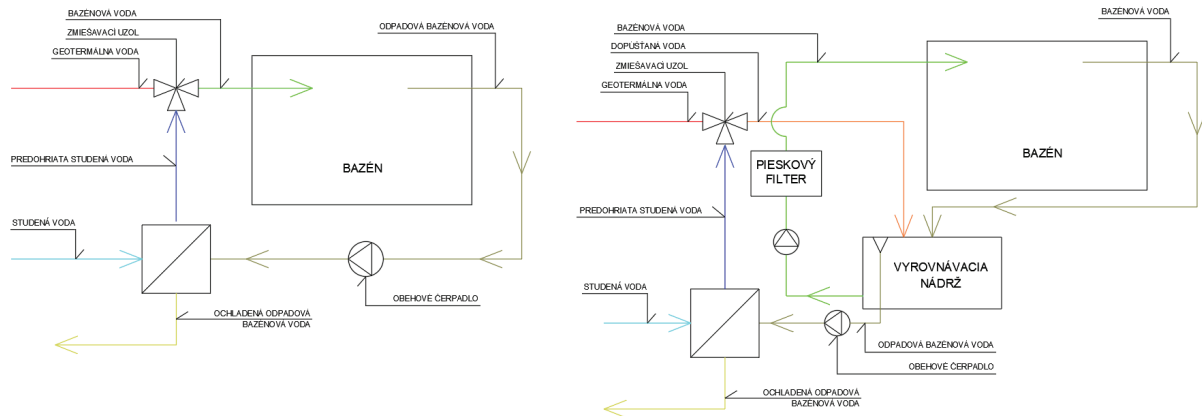

Obr. 1 Systém spätného získavania tepla z odpadovej bazénovej vody s využitím na predohrev studenej vody v prietokovom systéme (vl’avo) a cirkulačnom systéme (vpravo).

\section{METODIKA}

Pred samotným výpočtom objemových prietokov, je potrebné poznat' vstupné parametre riešeného bazéna, prípadne celého bazénového hospodárstva. Pre príklad výpočtu bol zvolený bazén, ktorého parametre vychádzajú z reálnych podkladov. Bol zvolený rekreačný oddychový bazén, pracujúci na prietokovom systéme, ktorého vodná plocha bola $295,0 \mathrm{~m}^{2}$. Híbka bazéna bola $1,25 \mathrm{~m}$ a jeho objem $368,0 \mathrm{~m}^{3}$. Geotermálny vrt poskytuje vodu s teplotou 
$70{ }^{\circ} \mathrm{C}$, ktorá sa mieša so studenou vodou s uvažovanou priemernou teplotou $15{ }^{\circ} \mathrm{C}$, na dosiahnutie požadovanej teploty bazénovej vody $38^{\circ} \mathrm{C}$. Vo výpočte sme uvažovali len s letnou prevádzkou bazéna, ktorá trvala 70 dní. Bazén bol mimo prevádzky počas 7 dní, kedy prebiehalo jeho vypúšt’anie, údržba a opätovné napúšt'anie. Vstupné hodnoty bazéna sú zhrnuté v Tabul'ke 1 .

Tab. 1 Vstupné hodnoty na výpočet energetickej bilancie bazéna.

\begin{tabular}{|c|c|c|c|c|c|c|}
\hline $\begin{array}{c}\text { Vodná } \\
\text { plocha } \\
\left(\mathrm{m}^{3}\right)\end{array}$ & $\begin{array}{c}\text { Objem } \\
\left(\mathrm{m}^{3}\right)\end{array}$ & $\begin{array}{c}\text { Híbka } \\
\text { (m) }\end{array}$ & $\begin{array}{c}\text { Geotermálna } \\
\text { voda } \\
\left({ }^{\circ} \mathrm{C}\right) \\
\end{array}$ & $\begin{array}{c}\text { Studená } \\
\text { voda } \\
\left({ }^{\circ} \mathrm{C}\right)\end{array}$ & $\begin{array}{c}\text { Bazénová } \\
\text { voda } \\
\left({ }^{\circ} \mathrm{C}\right) \\
\end{array}$ & $\begin{array}{l}\text { Prevádzka } \\
\text { (dni) }\end{array}$ \\
\hline 295,0 & 368,0 & 1,25 & 70 & 15 & 38 & 70 \\
\hline
\end{tabular}

Výpočet je potrebné spravit’ pre stav napúšt'ania a prevádzky bazéna. Pri výpočte prevádzkového stavu napúšt’ania aj prevádzky, je ciel'om výpočtu zistit' objemový prietok bazénovej vody, potrebnej na napustenie a prevádzku bazéna. Ked’že bazénová voda je zmiešaná z geotermálnej a studenej vody, výpočtom bude vyjadrený aj objem potrebnej zmiešanej bazénovej (BV), geotermálnej (GTV) a studenej vody (SV).

\section{VÝSLEDKY}

Výsledky ukázali, že na napustenie bazéna sedemkrát počas 70 dennej prevádzky, bude potrebných $2962,4 \mathrm{~m}^{3}$ zmiešanej bazénovej vody. Podiel geotermálnej vody v bazénovej vode bude $42 \%$ a podiel studenej vody $58 \%$. Počas prevádzky bazéna, ktorá bude trvat' 70 dní, bude potrebný objem bazénovej vody $10368,4 \mathrm{~m}^{3}$. Pomer miešania geotermálnej a studenej vody ostáva totožný aj počas prevádzky bazéna. Výsledky výpočtu pred vradením výmenníka tepla do okruhu odpadovej bazénovej vody sú zhrnuté v Tabul'ke 2.

Tab. 2 Výsledky výpočtu objemového prietoku a objemu bazénovej, geotermálnej a studenej vody pred zaradením výmenníka tepla do okruhu odpadovej vody.

\begin{tabular}{|c|c|c|c|c|c|c|}
\hline $\begin{array}{c}\text { Prevádzkový } \\
\text { stav }\end{array}$ & $\begin{array}{c}\text { Prietok } \\
\text { BV } \\
(1 / s)\end{array}$ & $\begin{array}{c}\text { Prietok } \\
\text { GTV } \\
(\mathrm{l} / \mathrm{s})\end{array}$ & $\begin{array}{c}\text { Prietok } \\
\text { SV } \\
(1 / \mathbf{s})\end{array}$ & $\begin{array}{c}\text { Objem } \\
\text { BV } \\
\left(\mathrm{m}^{3}\right)\end{array}$ & $\begin{array}{c}\text { Objem } \\
\text { GTV } \\
\left(\mathrm{m}^{3}\right)\end{array}$ & $\begin{array}{c}\text { Objem } \\
\text { SV } \\
\left(\mathrm{m}^{3}\right)\end{array}$ \\
\hline Napúšt'anie & 11,4 & 4,7 & 6,6 & 2962,4 & 1238,8 & 1723,6 \\
\hline Prevádzka & 1,5 & 0,7 & 0,8 & 10368,4 & 4335,9 & 6032,5 \\
\hline
\end{tabular}

Následne bol spravený rovnaký výpočet, ale po vradení výmenníka tepla do okruhu odpadovej bazénovej vody. Výmenníkom tepla bude prúdit' odpadová bazénová voda s teplotou približne $38{ }^{\circ} \mathrm{C}$ a studená voda s teplotou $15^{\circ} \mathrm{C}$. Na základe tohoto opatrenia, bude do zmiešavacieho uzla privádzaná predhriata studená voda na vyššiu teplotu. Následkom toho dôjde $\mathrm{k}$ zníženiu potrebného objemu geotermálnej vody, ktorá je čerpaná z geotermálneho vrtu. Výsledky ukázali, že objem geotermálnej vody je možné takýmto spôsobom znížit' o 13 \% a objem studenej vody zvýšit' o asi $13 \%$. Výsledky výpočtu objemového prietoku a objemu bazénovej, geotermálnej a studenej vody po zaradení výmenníka tepla do okruhu odpadovej vody sú uvedené v tabul'ke Tab. 3 .

Tab. 3 Výsledky výpočtu objemového prietoku a objemu bazénovej, geotermálnej a studenej vody po zaradení výmenníka tepla do okruhu odpadovej vody.

\begin{tabular}{|c|c|c|c|c|c|c|}
\hline $\begin{array}{c}\text { Prevádzkový } \\
\text { stav }\end{array}$ & $\begin{array}{c}\text { Prietok } \\
\text { BV } \\
(1 / s)\end{array}$ & $\begin{array}{c}\text { Prietok } \\
\text { GTV } \\
(\mathrm{l} / \mathrm{s})\end{array}$ & $\begin{array}{c}\text { Prietok } \\
\text { SV } \\
(1 / s)\end{array}$ & $\begin{array}{c}\text { Objem } \\
\text { BV } \\
\left(\mathrm{m}^{3}\right)\end{array}$ & $\begin{array}{c}\text { Objem } \\
\text { GTV } \\
\left(\mathrm{m}^{3}\right)\end{array}$ & $\begin{array}{c}\text { Objem } \\
\text { SV } \\
\left(\mathrm{m}^{3}\right)\end{array}$ \\
\hline Napúšt'anie & 11,4 & 3,8 & 7,6 & 2962,4 & 855,8 & 2106,6 \\
\hline Prevádzka & 1,5 & 0,5 & 1,0 & 10368,4 & 2995,3 & 7373,1 \\
\hline
\end{tabular}

Výsledky výpočtu taktiež ukázali, že na napustenie bazéna bude potrebný prietok bazénovej vody 11,4 1/s, ktorý sa rozdelí do niekol'kých napúšt'acích potrubí bazéna. Potrebný prietok na napúšt’anie bazéna ostáva nemenný pred aj po vradení výmenníka tepla do okruhu odpadovej vody. Počas napúšt’ania nie je možné znížit' potrebný objemový prietok geotermálnej vody, pretože z bazéna neodteká žiadna odpadová voda. Úspora geotermálnej vody však je možná počas prevádzky, kedy už z bazéna odteká odpadová voda s energetickým potenciálom, ktorý je možné využit'. Porovnanie výsledkov objemu bazénovej, geotermálnej a studenej vody počas napúšt’ania a prevádzky pred a po vradení výmenníka tepla do okruhu odpadovej vody je znázornené na Obr. 2 a Obr. 3. 


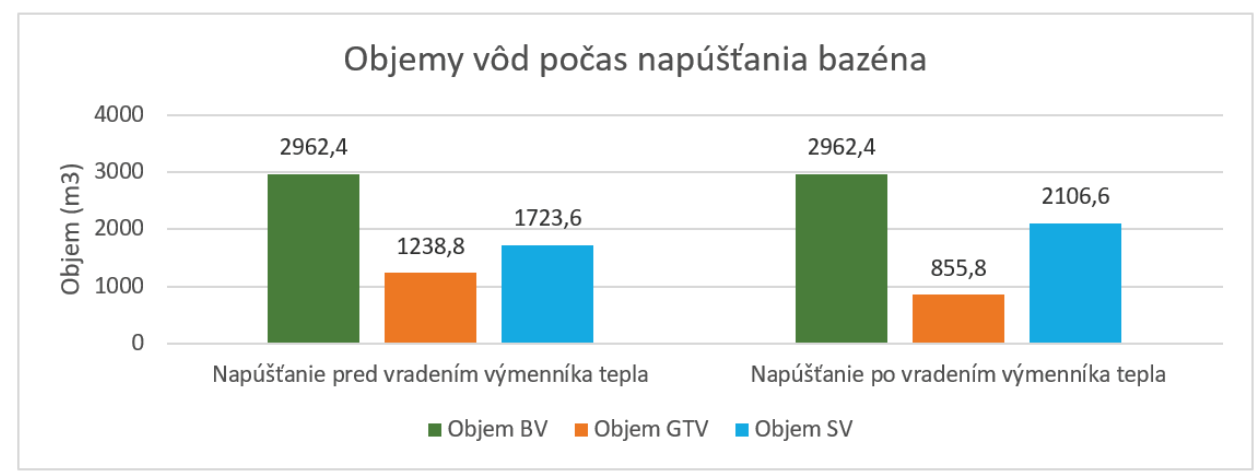

Obr. 2 Objem bazénovej, geotermálnej a studenej vody potrebnej počas napúšt’ania bazéna.

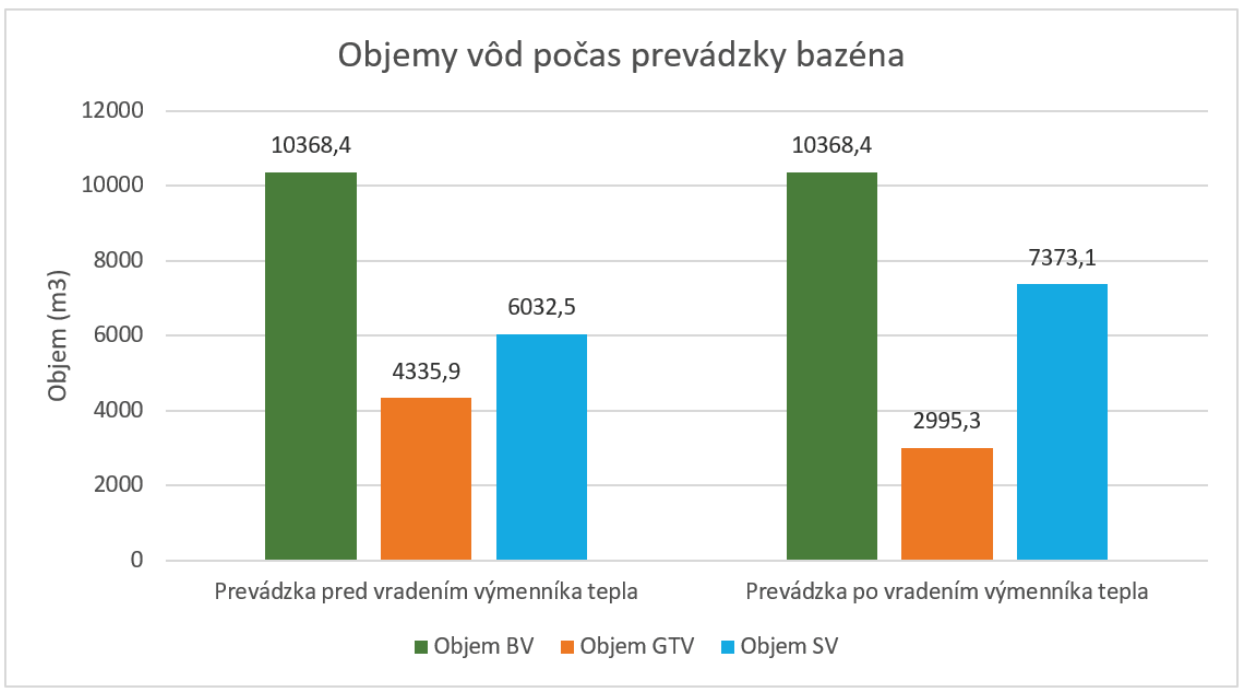

Obr. 3 Objem bazénovej, geotermálnej a studenej vody potrebnej počas prevádzky bazéna.

\section{DISKUSIA}

Výsledky výpočtu ukázali, že je možné dosiahnut' zníženie potrebného objemu geotermálnej vody na to, aby sme zabezpečili napúšt’anie bazéna s požadovanými parametrami bazénovej vody. V bazénovom systéme bez spätného získavania tepla z odpadovej bazénovej vody dosahujeme pomerne vysokú potrebu geotermálnej vody.

Po aplikácii energeticky úsporných opatrení v podobe vradenia rekuperačného výmenníka tepla do okruhu odpadovej bazénovej vody, dosiahneme zníženie potreby geotermálnej vody a zvýšenie potreby studenej vody na zabezpečenie rovnakých parametrov bazénovej vody. Vzhl'adom na to, že studená voda bude predhriata pomocou odpadového tepla, je možné zvýšit’ mieru využívania geotermálnej energie. V tomto prípade sa jedná o systém jednostupňového ochladenia odpadovej bazénovej vody, vd’aka ktorému je možné dosiahnut' teplotu odpadovej vody $26{ }^{\circ} \mathrm{C}$ z hl'adiska ochrany okolitého životného prostredia. Ďalšou možnost'ou je využit' systém dvojstupňového ochladenia odpadovej bazénovej vody. Systém zahŕn̆a dva stupne ochladenia odpadovej vody, pričom prvým stupňom je rekuperačný výmenník tepla a druhým tepelné čerpadlo voda - voda [9, 10]. Vd'aka tepelnému čerpadlu by bolo možné ochladit' odpadovú vodu na teplotu $15{ }^{\circ} \mathrm{C}$, ktorá je považovaná na hladinu nulovej energie vody, kedy voda už nemá žiadny energetický potenciál. Otázkou ostáva, či je vhodné vypúšt’anie odpadovej vody s teplotou $15^{\circ} \mathrm{C}$ do recipientu vzhl'adom na to, že minimálna teplota nie je legislatívne upravená. 


\section{ZÁVER}

Odpadová bazénová voda ktorú vo vel'kej miere produkujú termálne, ale aj netermálne kúpaliská, v sebe má vel'ký energetický potenciál, ktorý nie je nijak využivaný. Ciel’om príspevku bolo poukázat' niekol'ko možností spätného využívania tepla z odpadovej bazénovej vody. Príspevok bol bližšie zameraný na využívanie odpadového tepla v systéme predohrevu studenej vody, ktorá sa využíva v bazénovom hospodárstve na dosahovanie požadovaných parametrov bazénovej vody. Na základe predhriatia studenej vody na vyššiu teplotu, je možné dosiahnut' zníženie požadovaného objemu geotermálnej vody potrebnej na prevádzku bazénového hospodárstva. Toto je možné dosiahnut' pomocou energeticky úsporného opatrenia $\mathrm{v}$ podobe vradenia rekuperačného výmenníka tepla do okruhu odpadovej bazénovej vody, alebo aplikáciou aj druhého stupňa ochladenia odpadovej vody pomocou tepelných čerpadiel. Ciel'om systému spätného získavania tepla z odpadovej bazénovej vody je možnost' znížit' teplotu odpadovej bazénovej vody na hodnotu, pri ktorej je bezpečné jej vypúšt’anie do recipientu bez poškodenia okolitého životného prostredia. Ďalším aspektom je zníženie objemu geotermálnej vody čerpanej z geotermálneho vrtu, následkom čoho dôjde k predíženiu životnosti geotermálneho energetického systému. V neposlednom rade bude možné znížit' sankcie za znečist'ovanie životného prostredia, ktoré sú závislé na teplote odpadovej vody vypúšt’anej do recipientu. Dôležité je poukázat' aj na nedostatočné využívanie tejto energie, vzhl'adom na teplotu vôd, ktoré sú považované za odpad. Geotermálna energia je považovaná za obnovitel'ný zdroj energie, ale nešetrné zaobchádzanie môže spôsobit' vyčerpatel'nost' zdroja v priebehu desiatok rokov.

\section{Pod'akovanie}

Táto práca bola podporovaná Ministerstvom školstva, vedy, výskumu a športu SR prostredníctvom grantu VEGA 1/0303/2021, VEGA 1/0304/2021 a KEGA 005STU-4/2021.

\section{Použité zdroje}

[1] FRANKO, Ondrej, Oto FUSÁN, Miroslav KRÁL, Anton REMŠÍK, Marián FENDEK, Dušan BODIŠ, Vladimír DROZD a Konštantín VIKA. Atlas geotermálnej energie Slovenska. Štátny geologický ústav Dionýza štúra v Bratislave: Vydavatel'stvo Michala Vaška, Prešov, 1995. ISBN 80-85314-38-X.

[2] FRIČOVSKÝ, Branislav, Radovan ČERNÁK, Daniel MARCIN, Veronika BLANÁROVÁ, Katarína BENKOVÁ, Ondrej PELECH a Marián FENDEK. Geothermal Energy Use, Country Update for Slovakia. In: European Geothermal Congress 2019. Den Haag, The Netherlands: EGEC, 2019, 1 - 13. ISBN 978-2-9601946-1-6.

[3] Zákon 364/2004 o vodách a o zmene zákona Slovenskej národnej rady č. 372/1990 Zb. o priestupkoch v znení neskorších predpisov (vodný zákon) 364/2004 účinný od 09.04.2020.

[4] Nariadenie vlády 269/2010 Z.z. Slovenskej republiky z 25. mája 2010, ktorým sa ustanovujú požiadavky na dosiahnutie dobrého stavu vôd.

[5] Stiebel Eltron. Spätné získavanie tepla z odpadovej vody. ASB [online]. Bratislava: JAGA, 2018, 14. júna 2018 [cit. 2021-11-16]. Dostupné z: https:/www.asb.sk/stavebnictvo/technicke-zariadeniabudov/energie/spatne-ziskavanie-tepla-z-odpadovej-vody

[6] PERÁČKOVÁ, Jana a Veronika PODOBEKOVÁ. Jak využít teplo z kanalizace na př́pravu teplé vody v budovách? Tzbinfo [online]. Praha: 2014, 6.10.2014 [cit. 2021-11-16]. Dostupné z: https://voda.tzbinfo.cz/uspory-voda-kanalizace/11807-jak-vyuzit-teplo-z-kanalizace-na-pripravu-teple-vody-vbudovach

[7] KALÚS, Daniel a Matej KUBICA. Aplikace tepelně aktivních panelů v budovách s využitím OZE. TZB Haustechnik. 2020, 14(4), 57 - 60. ISSN 1803-4802.

[8] PREDAJNIANSKA, Anna a Ján TAKÁCS. Využití nízkoteplotní energie z termálních koupališt'. TZB Haustechnik. 2020, 14(3), 22 - 25. ISSN 1803-4802.

[9] KASSAI, Miklos. Heat Pump Heating System Development of Educational Building based on Energy, Economical and Environmental Impacts. Periodica Polytechnica Mechanical Engineering. 2019, 63(3), 207 - 213. ISSN 0324-6051. Dostupné z: doi:https://doi.org/10.3311/PPme.13872

[10] NYERS, Jozsef. COP and Economic Analysis of the Heat Recovery from Waste Water using Heat Pumps. Acta Polytechnica Hungarica. 2016, 13(5), 135 - 154. ISSN 1785-8860. 